\title{
Cotton Production Systems for Soil and Energy Conservation in Coastal Plain Soils
}

\author{
Ahmad Khalilian ${ }^{1}$, Michael W. Marshall ${ }^{2}$, Phillip B. Williams ${ }^{1}$, Jeremy K. Greene ${ }^{3}$, \\ Paul M. Porter ${ }^{4}$
}

${ }^{1}$ Department of Agricultural Sciences, Clemson University, Clemson, SC, USA

${ }^{2}$ Edisto Research and Education Center, Clemson University, Blackville, SC, USA

${ }^{3}$ Department of Plant and Environmental Sciences, Clemson University, Clemson, SC, USA

${ }^{4}$ Department of Agronomy and Plant Genetics, University of Minnesota, St. Paul, MN, USA

Email: akhlln@clemson.edu,pbw@clemson.edu,marsha3@clemson.edu,greene4@clemson.edu,

pporter@umn.edu, ^akhlln@clemson.edu

How to cite this paper: Khalilian, A., Marshall, M.W., Williams, P.B., Greene, J.K. and Porter, P.M. (2018) Cotton Production Systems for Soil and Energy Conservation in Coastal Plain Soils. American Journal of Plant Sciences, 9, 1500-1513. https://doi.org/10.4236/ajps.2018.97110

Received: May 15, 2018

Accepted: June 23, 2018

Published: June 26, 2018

Copyright $\odot 2018$ by authors and Scientific Research Publishing Inc. This work is licensed under the Creative Commons Attribution International License (CC BY 4.0).

http://creativecommons.org/licenses/by/4.0/

\begin{abstract}
Cotton growers in the southern USA are facing new production problems that are reducing farm profits and sustainability: 1) herbicide-resistant weeds are spreading throughout the Southeast, 2) thrips are consistently ranked as an important insect pest group Beltwide, 3) the most effective tool for managing nematodes and thrips (aldicarb) currently is only available in the southeastern USA in limited amounts, and 4) fuel costs have increased significantly over the last ten years. An interseeding system was developed at Clemson University that allows planting of cotton into standing wheat, about $2-3$ weeks before wheat harvest. This system, which combines benefits of crop residue and minimum tillage operations, has the potential to alleviate many of the production problems cited above, while enhancing farm profits and soil properties. Crop residue associated with the interseeding production system reduced weed populations and required significantly less herbicide inputs compared with the conventional system. Columbia lance nematodes populations were reduced in the interseeding system by $83 \%$ without an application of nematicide. Populations of thrips were reduced by $74 \%$ in the interseeding production system. No differences were observed between the yields from interseeded and the conventional full-season cotton. However, revenues from the interseeding system were higher due to harvest of the wheat crop. In addition, the interseeding system consumed $35 \%$ less fuel than the conventional production systems.
\end{abstract}

\section{Keywords}

Cotton, Relay Cropping, Pest Management, Energy Requirements, Controlled 
Traffic, Interseeding

\section{Introduction}

Cotton is one of the most economically important crops in the southern USA with an estimated production value of over $\$ 7$ billion [1]. However, current production practices involve high inputs and minimal soil conservation practices. Declining government subsidies, fluctuating world market prices and the necessity for conservation plans on highly erodible lands make it obvious that alternative production systems are needed to maintain profitability in cotton production.

One major advantage the southern U.S. has over other crop production areas is a long growing season which makes it possible to double-crop summer crops after harvesting of the winter crop. The most popular double-cropping system in the southern U.S. is winter wheat followed by soybean. Some growers are currently double-cropping cotton after wheat. However, the longer growing season requirements for cotton compared to soybean limit the yield potential for double-cropped cotton, due to delayed planting window after wheat harvest.

Recently, growers in the southern U.S. are facing new production problems that are either reducing farm profits and sustainability or threatening soil conservation practices:

- Herbicide-resistant weeds are spreading throughout the Southeast and soil-applied residual herbicides have become the most adopted practice to manage herbicide-resistant weeds (such as Palmer amaranth [Amaranthus palmeri $\mathrm{S}$. Wats]). An aggressive soil and foliar herbicide program can cost over $\$ 120 /$ ha. Soil conservation gains achieved in the last 20 years are threatened by use of tillage to manage herbicide resistant weeds [2]. Cereal crops can be used effectively to suppress herbicide-resistant weeds [3] [4], since they have an allopathic effect on weeds for up to 6 weeks. In addition, living mulches are better at suppressing weeds than dead mulches [5].

- Control costs for and damage caused by insects also pose significant production problems in cotton. According to loss estimates provided in the Proceedings of the Beltwide Cotton Production Conferences, cotton producers across the USA lost about $\$ 100$ million to thrips during 2008-2010 [6]. With at-plant preventative treatments and foliar applications combined, control costs during the same period are in the tens of millions as well. Thrips were ranked as the second most important group of cotton insect pests in 2011 across the USA [7], but represented the most important group in the Southeast in 2015 [8].

- Additionally, nematodes cause hundreds of millions of dollars in yield losses annually to USA cotton [9] [10]. Nematode management relies heavily on the use of nematicides such as aldicarb (AgLogic 15G - \$74/ha) [11] [12]. How- 
ever, the most effective tool for managing nematodes (aldicarb-AgLogic $15 \mathrm{G})$ currently is only available in the southeastern USA in limited amounts [4]. Cereal crops (such as wheat) can be used to suppress populations of southern root-knot and Columbia lance nematodes [4] [13].

- Finally, the cost of fuel represents over $30 \%$ of the total costs of owning and operating farm machinery [14] [15]. This cost could increase further as the price of fuel rises in the future. It is important that every effort be made to reduce energy use in agricultural production from both standpoints of economics and availability.

The double-cropping system developed at Clemson University allows interseeding or planting of a summer crop, such as soybean, cotton, or peanut into a second winter crop, such as winter wheat, approximately 2 - 3 weeks before harvest of the second crop [16] [17]. This system has the potential to mitigate all the production problems discussed previously.

\section{Objectives}

The objectives of this study were to: 1) Determine proper production strategies for interseeding cotton into standing wheat; 2) Compare the yields of interseeded cotton with those of conventional mono-cropped full season cotton, and cotton planted after wheat harvest; 3 ) Determine the effects of interseeding system on pest management; soil properties; fuel consumption and crop responses in cotton production; 4) Determine the effects of cropping systems on cotton aboveground growth and development, as well as node length and boll location; and 5) Evaluate fiber quality of interseeded cotton.

\section{Methodology}

\subsection{Equipment}

1) Clemson Interseeder/planter: The interseeding system [16] was modified to plant wheat and later interseed cotton, soybeans, or peanuts into standing wheat rows. The new no-till drill/planter (Figure 1) was constructed using four major components: a) three-point hitch assembly with forks to support seeding units that are attached to the toolbar, b) an air applicator for metering the seed, c) dual toolbars for mounting of seed openers and depth/drive wheels, and d) the seed opening mechanisms.

The three-point hitch assembly that supports the seeding unit while attached to the tractor can be transferred between toolbars equipped with different seed opening mechanisms. The seeding unit (Gandy Orbit-Air Applicator, Model 6216C, Gandy Company, Owatonna, MN, USA) is equipped with a $635 \mathrm{~L}$ hopper that supplies 16 metering wheels with individual gates that can be closed to select the desired number of outlets. An adjustable speed blower powered by a hydraulic motor provides air pressure to individual Venturi chambers that receive the metered seeds and transfer them though tubes to openers. The loading platform location was shifted to the fan side of the seeding unit and the lid mounting was 


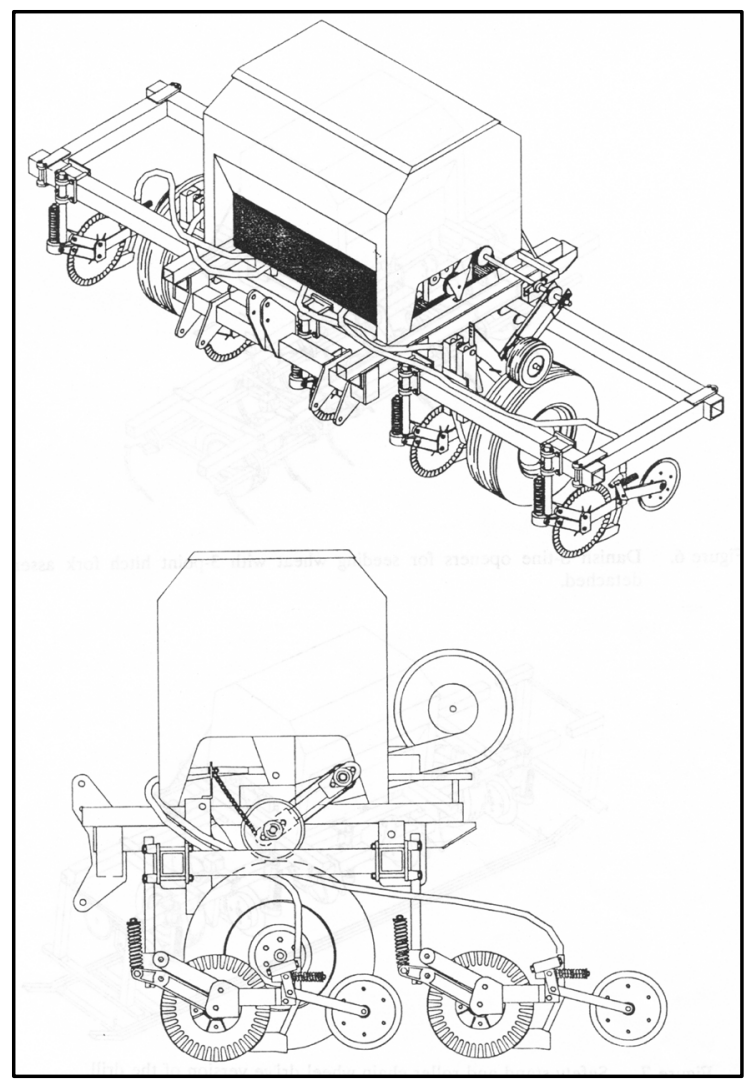

Figure 1. Schematic diagrams of the Clemson interseeder planter/no-till drill.

reversed to provide rear-loading of the seed and to allow the operator to view the seed metering operation.

The seeding rate of the Orbit-Air unit is adjusted through an infinitely Variable Zero-Max control (Zero-Max, Inc., Plymouth, MN, USA) powered by a ground wheel drive. Color coded metering wheels are available for different seed shapes and sizes (such as wheat, soybean, corn, peanuts, and cotton seeds). In this study, the yellow metering wheels were used for cotton.

Using one of the depth control wheels, a wheel-on-wheel drive arrangement was used to drive the Orbit-/Air unit (Figure 1). Provisions were made to allow downward movement of the drive wheels to maintain continuous soil contact to accommodate uneven terrain or lifting of the machine by the seed opening mechanisms.

Seed opening system used Model 2977 Yetter Seeder Coulters (Yetter Farm Equipment, Colchester, IL, USA) mounted on square toolbar(s) (Figure 1) and employed for wheat planting and later interseeding summer crops (soybeans, cotton, etc.) or for conventional no-till applications. Seed tube material supplied by Gandy delivered seed via air to a steel tube fixed to the rear of the Yetter Seeder Coulter seed slot opener positioned directly behind a $43 \mathrm{~cm}$ ripple coulter. Gage wheels (depth bands attached to coulters, $28 \mathrm{~cm} \times 6.5 \mathrm{~cm}$ ) were used in all planting studies reported. A $2.5 \mathrm{~cm}$ wide and $30 \mathrm{~cm}$ diameter rubber coated 
press wheel followed the slot opener.

2) Commercial equipment modification: To make this technology more adoptable by producers, commercial drills were modified. For planting small grain, conventional grain drills (19-cm row spacing) were modified by blocking some of the seed tubes for planting wheat. For cotton farmers on $97-\mathrm{cm}$ row spacing, one out of every five seed tubes of the grain drill were blocked to provide skip rows for interseeding cotton. This setup provided skip rows (blanks) in wheat (at 97-cm intervals) for interseeding cotton the following May (Figure 2(Top)).

In addition, a 4-row John Deere 1700 vacuum planter (John Deere Co., Moline, IL, USA), which is commonly used by row crop farmers, was modified for interseeding cotton into the standing wheat. The standard wide planting units were replaced with four units of JD narrow row planters (narrow twin row unit). This modified row unit fit in the narrow skip space in the standing rows without damaging to the wheat crop (Figure 2(Bottom)).

\subsection{Field Tests}

Two sets of tests were conducted during the 2013 to 2015 growing seasons, to achieve the objectives of this study. The experimental design for both tests was a randomized complete block design with six replications. Both tests were conducted on a Varina loamy sand soil (clayey, kaolinitic, thermic plinthic Paleudults), a typical productive soil in the Southeastern Coastal Plain. Test plot dimensions were $3.9 \times 30 \mathrm{~m}$.

Test \# 1: the following four treatments were established on the indicated dates:

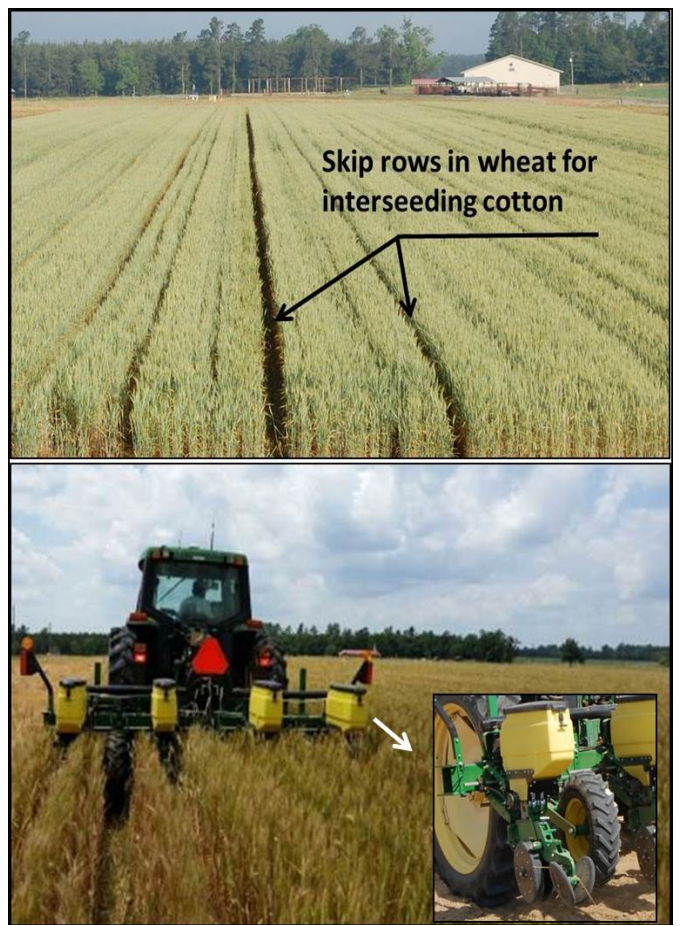

Figure 2. Skip rows in wheat and modified John Deere 1700 vacuum planter. 
1) Cotton interseeded into standing wheat about four weeks before wheat harvest, around May $1^{\text {st }}$. Wheat was planted in the fall using the Clemson interseeder drill (Figure 1) following a deep tillage with Paratill (Bingham, Lubbock, $\mathrm{TX)}$

2) Same as treatment 1, except that cotton was interseeded into wheat about two weeks before wheat harvest (Third week in May).

3) Conventional full season cotton, no fall deep tillage, disk, subsoil-bed, strike off beds and plant cotton with a John Deere 7000 vacuum planter (John Deere Co., Moline, IL, USA) around first week in May.

4) Conventional double crop, fall chisel plowed prior to wheat planting with a grain drill, cotton planted after wheat harvest, using a KMC subsoiler-planter (Kelley Manufacturing Co. Tifton, GA), around first week in June.

Test \#2: This test was designed to determine the effects of interseeding system on pest management; soil properties; fuel consumption and crop responses in cotton production. Therefore this test had only two treatments:

1) Cotton interseeded into standing wheat (Figure 2(Top)) using the JD 1700 narrow-vacuum planter (Figure 2(Bottom)), and

2) Conventional cotton planted with the KMC subsoiler-planter. Row spacing for both interseeded and conventional cotton was $97 \mathrm{~cm}$ and was planted around mid-May.

A John Deere 4400 grain combine (John Deere Co., Moline, IL, USA) with a 3.9-m platform header was modified to change the wheel spacing to $1.93 \mathrm{~m}$ to conform to the controlled-traffic pattern. The combine was also equipped with an AgLeader yield monitor (Ag Leader Technology, Ames, Iowa), which allowed us to map on-the-go the variation in wheat yields among the different treatments.

To determine the effects of deep tillage equipment on soil compaction, a microcomputer-based, tractor-mounted recording penetrometer [4] was used to quantify soil penetration resistance. Penetrometer data were collected about two and seven months after fall tillage and immediately after cotton harvest.

For test \#2, weeds, insects, and nematodes population densities were monitored during the season, for each treatment to compare the effect of interseeding techniques on pest incidence. Every year, soil cores were collected from test plots and analyzed for nematode species and population densities. Weed biomass was collected using a $0.45 \mathrm{~m}^{2}$ quadrat during and at the end of the season to quantify effect of residue on weed populations.

The cotton plots were harvested depending on maturity of the treatments. The mono-crop and the early interseeded plots were harvested with a spindle picker, equipped with either an AgLeader yield monitor (Ag Leader Technology, Ames, Iowa)or a weighing basket, around second week in October while the later maturing interseeded plots were harvested around the last week in October. Plant height, plant population and stalk losses were determined at harvest. In order to collect plant and ground losses, each plot was hand racked and any cotton falling 
to the ground was picked up by hand so that prior to initial picking all plots were absolutely clean. After machine harvesting, a 3-m section was established in the two middle rows of each plot (midway in the plots) and any cotton falling to the ground was collected and weighed to determine ground losses. In addition, any cotton remaining on the stalk above ground was also hand-picked and weighed to determine plant losses. Plant height and plant population were measured from the same 3-m sections.

\section{Results and Discussion}

Both the modified John Deere 1700 vacuum planter (John Deere Co., Moline, IL, USA) and the Clemson interseeder/drill successfully planted the cotton in the skip rows of the standing rows of wheat. Small beds generated during wheat planting provided an excellent non-compacted zone for the subsequent interseeding operation.

\subsection{Test \#1}

Soil cone index data (Table 1 and Table 2) showed that, even without spring deep tillage, soil resistance in interseed crop rows (Treatments 1 and 2) remained low (below $2.07 \mathrm{MPa}$ ) throughout the season. This indicates that one tillage operation in the fall, deep enough to disrupt root inhibiting hardpans; in conjunction with controlled traffic patterns associated with the interseeding system, eliminated the need for an additional deep tillage in the spring prior to planting cotton. In addition, cone index data collected from crop row after cotton harvest showed the residual effect of deep tillage operations could extend for one additional year in coastal plain soils, when controlled traffic is employed. This is in agreement with the previous results reported by the investigators [17] [18]. Data from Table 2 showed that the traffic areas were firm, even in the top $15 \mathrm{~cm}$ of soil profile, which made it possible to interseed cotton immediately after a rainfall.

Excellent stands of cotton were achieved with all treatments. For Test \#1, the plot area had been prepared to permit irrigation, to insure against stand loss in early interseeded cotton crop (treatment 1). For this treatment, the wheat was

Table 1. Cone index values ( $\mathrm{MPa})$ in a cotton row for different treatments, at two dates and three ranges of depths from soil surface (Test \#1).

\begin{tabular}{ccccccc}
\hline \multirow{2}{*}{$\begin{array}{c}\text { Treatment } \\
\text { No. }\end{array}$} & \multicolumn{3}{c}{ Mid-June } & \multicolumn{3}{c}{ After Harvest (November) } \\
\cline { 2 - 7 } & $\mathbf{0 - 1 5} \mathbf{c m}$ & $\mathbf{1 5}-\mathbf{3 0} \mathrm{cm}$ & $\mathbf{3 0}-\mathbf{4 5} \mathrm{cm}$ & $\mathbf{0}-\mathbf{1 5} \mathrm{cm}$ & $\mathbf{1 5}-\mathbf{3 0} \mathrm{cm}$ & $\mathbf{3 0 - 4 5 \mathrm { cm }}$ \\
\hline 1 & $0.294 \mathrm{a}^{*}$ & $0.854 \mathrm{bc}$ & $1.302 \mathrm{~b}$ & $0.441 \mathrm{a}$ & $0.997 \mathrm{~b}$ & $1.267 \mathrm{~b}$ \\
2 & $0.287 \mathrm{a}$ & $0.882 \mathrm{bc}$ & $1.351 \mathrm{~b}$ & $0.413 \mathrm{a}$ & $0.980 \mathrm{~b}$ & $1.323 \mathrm{~b}$ \\
3 & $0.315 \mathrm{a}$ & $1.239 \mathrm{a}$ & $2.058 \mathrm{a}$ & $0.406 \mathrm{a}$ & $1.092 \mathrm{~b}$ & $1.540 \mathrm{a}$ \\
4 & $0.175 \mathrm{a}$ & $0.707 \mathrm{c}$ & $1.274 \mathrm{~b}$ & $0.339 \mathrm{a}$ & $1.197 \mathrm{a}$ & $1.512 \mathrm{a}$ \\
\hline
\end{tabular}

*Values in the same column followed by the same letter are not significantly different at the $95 \%$ confidence level. 
Table 2. Cone index values $(\mathrm{MPa})$ in a traffic lane for different treatments, taken after cotton harvest (Test \#1).

\begin{tabular}{cccc}
\hline \multirow{2}{*}{ Treatment No. } & \multicolumn{3}{c}{ After Harvest (November) } \\
\cline { 2 - 4 } & $\mathbf{0 - 1 5} \mathbf{c m}$ & $\mathbf{1 5}-\mathbf{3 0} \mathbf{c m}$ & $\mathbf{3 0 - 4 5} \mathbf{c m}$ \\
\hline 1 & $1.981 \mathrm{a}$ & $2.037 \mathrm{a}$ & $1.512 \mathrm{~b}$ \\
2 & $2.037 \mathrm{a}$ & $2.079 \mathrm{a}$ & $1.582 \mathrm{~b}$ \\
3 & $1.610 \mathrm{a}$ & $1.177 \mathrm{a}$ & $1.771 \mathrm{ab}$ \\
4 & $1.946 \mathrm{a}$ & $2.310 \mathrm{a}$ & $1.995 \mathrm{a}$ \\
\hline
\end{tabular}

${ }^{*}$ Values in the same column followed by the same letter are not significantly different at the $95 \%$ confidence level.

still green and was removing water at a rapid rate. All the interseeded and double-cropped plots had better plant emergence than the conventional mono-cropped plots. Similar results were also obtained for plant populations at the harvest. There were no significant differences in plant height at harvest between the tillage/planting treatments.

In all three years, wheat yields were not affected by row spacing or interseeding. Wheat yield for grain drill (19 $\mathrm{cm}$ spacing between wheat rows) averaged 4039,3971 , and $5384 \mathrm{~kg} / \mathrm{ha}$, for year one, two, and three, respectively. For wheat crop with skip rows used for interseeding cotton (33-cm skips at $97-\mathrm{cm}$ intervals), yields were 4105,3937 , and $5371 \mathrm{~kg} / \mathrm{ha}$, for the same years, respectively. The seeding rates for both systems were the same. Comparison of wheat yield from interseeded and doubled-cropped plots indicated that interseeding cotton between rows of standing wheat did not decrease wheat yield. Similar results were reported by Khalilian et al., 1991 [17].

Internode length for plants in each treatment were recorded 54 and 89 days after planting and the boll location was determined prior to cotton harvest. The wheat stubble played an important role in the height of the lower nodes. By 89 days after planting. The height of the fourth node averaged $22 \mathrm{~cm}$ for the mono-cropped treatments versus $38 \mathrm{~cm}$ for the interseeded treatments (Figure 3 ). For cotton in the mono-cropped plots over $15 \%$ of the bolls were formed on or below the fifth node which averaged $27 \mathrm{~cm}$ above the ground, whereas. For the interseeded and double-cropped plots the number of bolls formed on or below the fifth node was under $6 \%$ and averaged $41 \mathrm{~cm}$ above the ground. A yield loss due to inability of the cotton picker to pick low bolls was greatest for the mono-cropped treatment. Averaged over two years, the stalk loss (the amount of cotton yield lost on plant), was $14 \%$ for mono crop and $6 \%$ for the interseeded and double-crop treatments.

There was no significant difference in yield between cotton interseeded into standing wheat two weeks before harvest (Figure 4, Treatment 2), and conventional mono-cropped cotton in all three years. However, in year one, cotton interseed two weeks before harvest, produced higher yield than other treatments. Double-cropped cotton planted after wheat harvest (Treatment 4) produced significantly less yield compared to the rest of the treatments. Also, there was a 


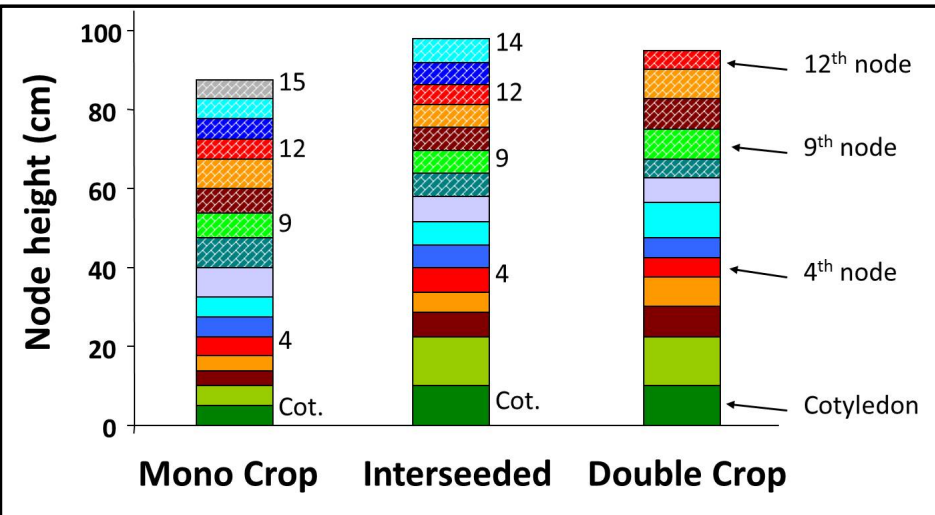

Figure 3. Node height of cotton 89 days after planting.

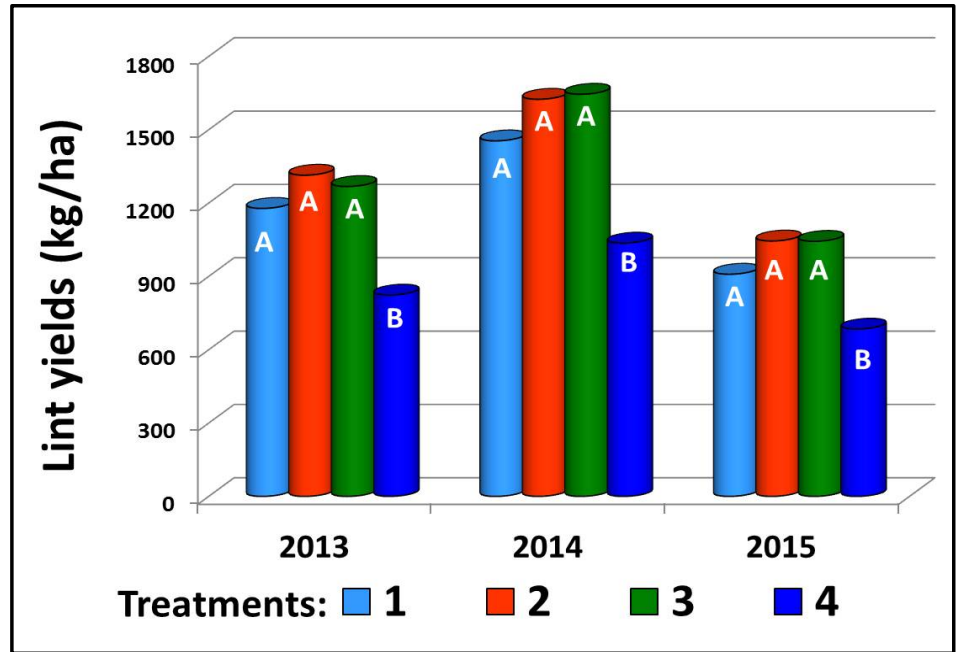

Figure 4. Effects of planting methods on cotton lint yields (Test \#1). Yield values within a year followed by the same letter are not significantly different at the $95 \%$ confidence level.

difference in yield between interseeded plots planted four weeks (Treatment 1) and two weeks before wheat harvest (Treatments 2). This is because for treatment 1 , the wheat was still green and was removing water at a rapid rate. However, this effect should be subjected to further study.

Figure 5 shows the fuel requirements for three different cropping systems for cotton production. The conventional double-cropped cotton planted after wheat harvest required $86 \mathrm{~L} / \mathrm{ha}$ or about $53 \%$ more fuel than interseeding system, which required $56 \mathrm{~L} / \mathrm{ha}$. Likewise, mono-crop cotton required $23 \%$ higher fuel than interseeded cropping systems.

There was no consistent evidence of difference in quality factors for the treatments of this study. Table 3 shows the results of HVI test for the year one of the study. Micronaire (MIC) values for all treatments were in the range of 3.5 to 4.2 the no-discount range. There were no significant differences in Upper Half Mean Length (UHML), Uniformity Index (LUI), Strength (STR), Yellow Content $(+\mathrm{B})$, Color Grades (CGRD), and Short fiber content (SFCW) among the 


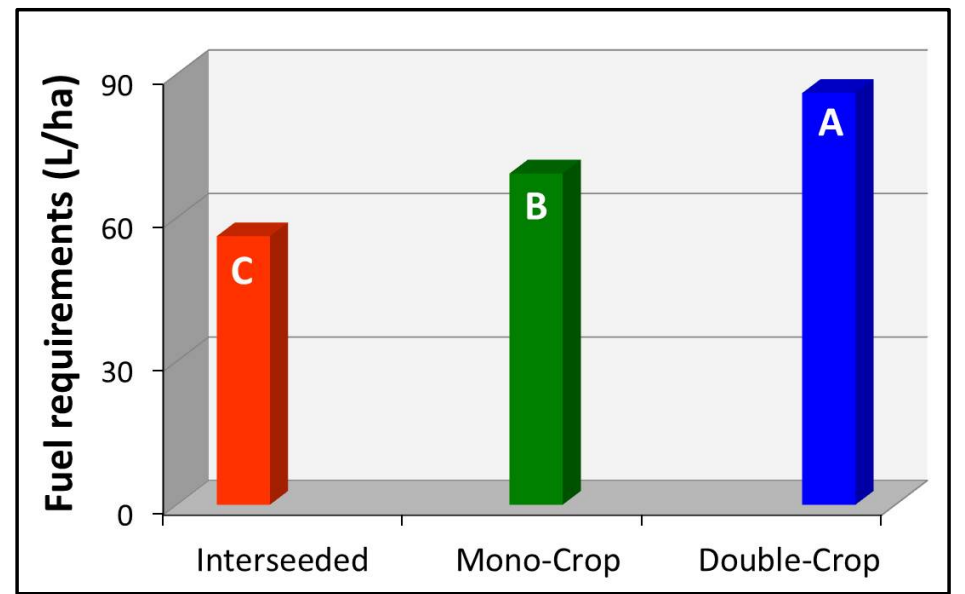

Figure 5. Effects of planting methods on cotton lint yields (Test \#1).

Table 3. HVI test results for the year one of the study Test \#1).

\begin{tabular}{cccccccc}
\hline TRT & MIC & UHML & LUI & STR & +B & CGRD & $\%$ SFCW \\
\hline 1 & $3.5 \mathrm{~b}^{*}$ & $1.1 \mathrm{a}$ & $80.4 \mathrm{a}$ & $25.7 \mathrm{a}$ & $6.9 \mathrm{~b}$ & $49.3 \mathrm{a}$ & $10.0 \mathrm{a}$ \\
2 & $3.9 \mathrm{ab}$ & $1.1 \mathrm{a}$ & $81.2 \mathrm{a}$ & $24.4 \mathrm{a}$ & $6.5 \mathrm{~b}$ & $42.7 \mathrm{~b}$ & $9.1 \mathrm{ab}$ \\
3 & $4.2 \mathrm{a}$ & $1.1 \mathrm{a}$ & $81.9 \mathrm{a}$ & $24.9 \mathrm{a}$ & $6.8 \mathrm{~b}$ & $47.7 \mathrm{ab}$ & $8.0 \mathrm{~b}$ \\
4 & $3.8 \mathrm{ab}$ & $1.1 \mathrm{a}$ & $81.3 \mathrm{a}$ & $25.4 \mathrm{a}$ & $6.7 \mathrm{~b}$ & $42.7 \mathrm{~b}$ & $8.8 \mathrm{ab}$ \\
\hline
\end{tabular}

*Values in a column followed with the same letter are not significantly different at the $95 \%$ confidence level.

rest of the treatments. Similar results were obtained for the years two and three of the Test \#1.

\subsection{Test \#2}

Similar to Test \#1, there were no differences in yield between mono-cropped and interseeded cotton in all three years. However, revenues from the interseeded cotton were higher due to harvest of the wheat crop (about 4000 to $4500 \mathrm{~kg} / \mathrm{ha}$ ). Figure 6 shows cotton lint yields for conventional and interseeded system for the 2013 to 2015 growing seasons. Conventional cotton production required deep tillage with a strip-till system. However, due to controlled-traffic patterns associated with the interseeding system, deep tillage before wheat benefited interseeded cotton; therefore, conventional production methods required 53\% more fuel than in the interseeding system.

Crop residue associated with the wheat in the interseeding production systems significantly reduced weed infestations in cotton. Figure 7 shows an example of reduction in Palmer amaranth, yellow nutsedge (Cyperus esculentus L.), and annual grass (Digitaria spp) biomass due to cropping systems in 2014. No herbicides were applied to the interseeded cotton plots, while the conventional mono-cropped cotton received at least two applications of herbicides. This resulted in a savings of about $\$ 88$ per hectare.

Nematode population densities (per $100 \mathrm{cc}$ of soil) were significantly reduced in the interseeded cotton fields due to wheat residue. The reductions in Columbia 


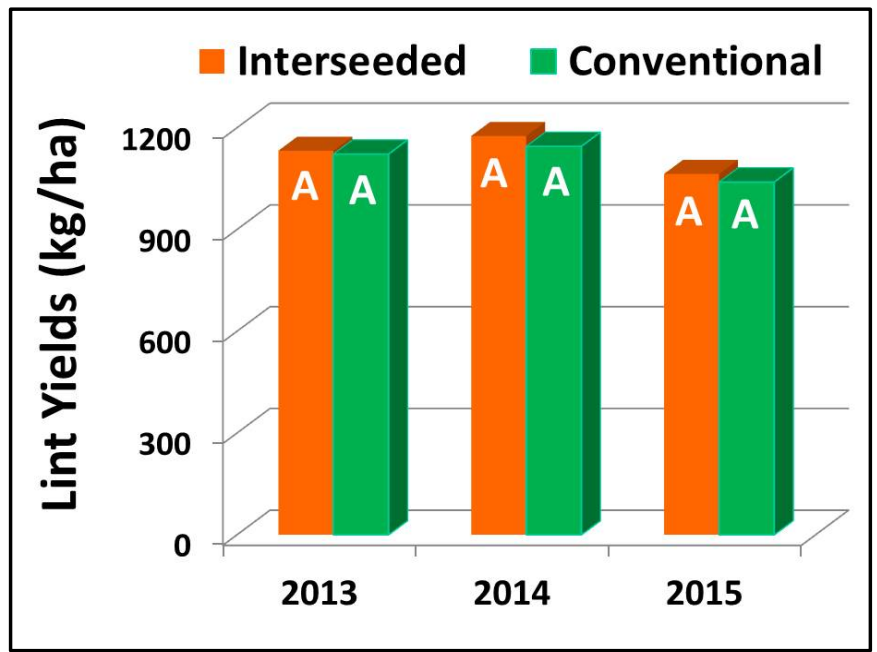

Figure 6. Effects of planting methods on cotton lint yields (Test \#2).

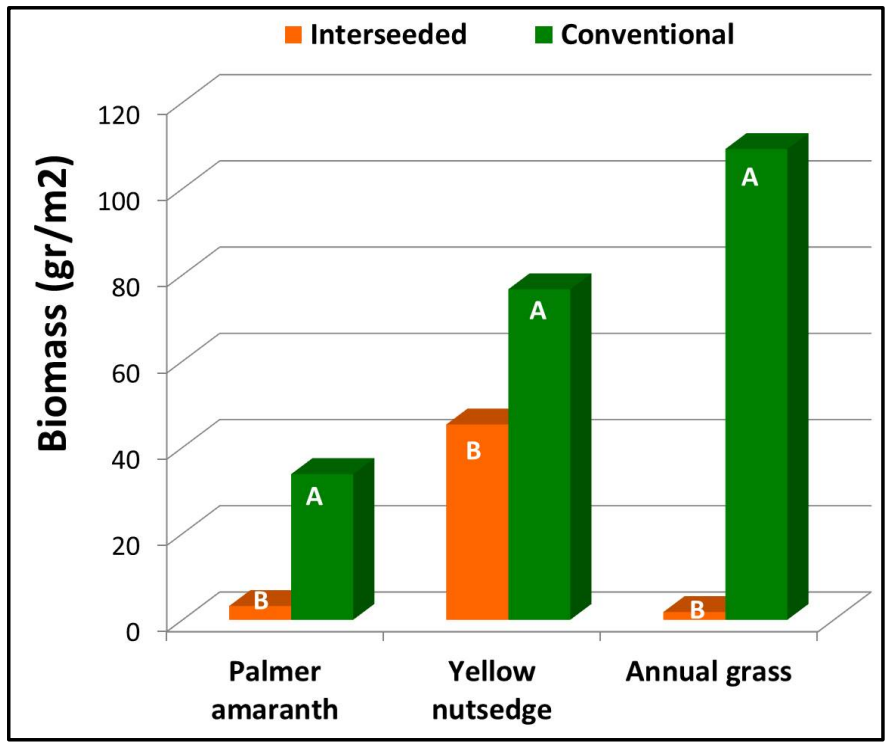

Figure 7. Effects of planting methods on weed biomass in cotton (Test \#2).

Lance were $35 \%$ and $80 \%$ for the 2013 and 2014 growing seasons, respectively, without applying pesticides (Table 4). In 2015, the interseeded cotton production system significantly reduced root-knot nematode population densities (89\%) compared to conventional system. Thrips populations in 2014 were 3.8 per 10 cotton plants in the interseeding compared to 14.6 per 10 cotton plants in the conventional system, a $74 \%$ reduction in thrip numbers between the two production systems. Similar results were reported by researchers at the North Carolina State University [19]. They reported that, interseeding may be an effective thrips management strategy in regions with high thrips population.

\subsection{Limitations}

Usually at the time of interseeding cotton into standing wheat (about two weeks 
Table 4. Effects of cropping method on soil OM, available K, nematodes, and thrips (Test $\# 2)$.

\begin{tabular}{ccccc}
\hline & Year & Interseeded & Conventional & $\%$ Change \\
\hline$\% \mathrm{OM}$ & $2013^{\star}$ & $1.15 \mathrm{a}$ & $0.87 \mathrm{~b}$ & $32 \%$ \\
& 2014 & $1.25 \mathrm{a}$ & $0.80 \mathrm{~b}$ & $56 \%$ \\
& 2015 & $1.5 \mathrm{a}$ & $1.2 \mathrm{~b}$ & $25 \%$ \\
$\mathrm{~K}(\mathrm{~kg} / \mathrm{ha})$ & 2013 & $112 \mathrm{a}$ & $103 \mathrm{~b}$ & $9 \%$ \\
& 2014 & $121 \mathrm{a}$ & $91 \mathrm{~b}$ & $33 \%$ \\
Columbia & 2015 & $141 \mathrm{a}$ & $118 \mathrm{~b}$ & $20 \%$ \\
lance/100 cc soil & 2013 & $65 \mathrm{~b}$ & $100 \mathrm{a}$ & $-35 \%$ \\
Root-knot/100 cc soil & 2014 & $70 \mathrm{~b}$ & $400 \mathrm{a}$ & $-80 \%$ \\
Thrips/10 plants & 2015 & $12 \mathrm{~b}$ & $106 \mathrm{a}$ & $-89 \%$ \\
\hline
\end{tabular}

*Values in the same row followed by the same letter are not significantly different.

before wheat harvest), the wheat crop is still green and actively removing water. Therefore, in southeastern USA, interseeding should be done following a rainfall of about $1-\mathrm{cm}$, or if available, the same amount of irrigation water should be applied to the field. Delayed planting could result in lower yields of interseeded cotton. In addition, this practice requires a specialized planter with row units narrow enough to fit in the skip space in the standing wheat rows, without damaging to the wheat crop.

\section{Conclusions}

Based on these results, cotton can successfully be interseeded into standing wheat with yields similar to those of the conventional full season mono-crop cotton. In southeastern USA, interseeding should be done following a rainfall of about $1-\mathrm{cm}$ (about two weeks before wheat harvest). There was no significant difference in yield between cotton interseeded into standing wheat two weeks before harvest and conventional mono-cropped cotton in all three years. Double-cropped cotton planted after wheat harvest produced significantly less yield compared to the rest of the treatments. Deep tillage before small grain planting also benefitted cotton due to controlled traffic patterns associated with the interseeding system. The residual effect from the fall deep tillage operation was extended into the following year when controlled traffic interseeding system was used.

The interseeding system required significantly less energy compared to conventional mono-cropped and double-cropped cotton planted after wheat harvest. Crop residue associated with the interseeding production system reduced weed densities and required fewer herbicide applications compared with the conventional system. Interseeded cotton positively impacted soil properties by 
increasing organic matter content and available K. Nematode population densities were reduced significantly in the interseeding system. In addition, thrips populations were also reduced by $74 \%$ in the interseeded cotton.

\section{Acknowledgements}

Technical Contribution No. 6653 of the Clemson University Experiment Station. This material is based upon work supported by NIFA/USDA, under project number SC-1700540. The authors also acknowledge the funding support of the USDA/NRCS and Clemson Public Service Activities.

\section{Disclaimer}

Mention of a trade name does not imply endorsement of the product by Clemson University to the exclusion of others that might be suitable.

\section{References}

[1] United States Department of Agriculture, National Agricultural Statistics Service, Crop Production Summary (2017). https://www.usda.gov/nass/PUBS/TODAYRPT/cropan17.pdf

[2] David, S., Culpepper, S., Owen, M., Price, A. and Wilson, R. (2012) Herbicide-Resistant Weeds Threaten Soil Conservation Gains: Finding a Balance for Soil and Farm Sustainability. Council for Agricultural Science and Technology (CAST). Issue Paper 49, 1-16.

http://www.cast-science.org/download.cfm?PublicationID=52723\&File=f030178260 35d0a1682777684a1c52424352

[3] Hoffman, M.L., Weston, L.A., Synder, J.C. and Regnier, E.E. (1996) Allelopathic Influence of Germination Seeds and Seedlings of Cover Crops on Weed Species. Weed Science, 44, 579-584.

[4] Marshall, M.W., Williams, P., Nafchi, A.M., Maja, J.M., Payero, J., Mueller, J. and Khalilian, A. (2016) Influence of Tillage and Deep Rooted Winter Cover Crops on Soil Properties, Pests, and Yield Responses in Cotton. Journal of Soil Sciences, 6, 149-158.

[5] Hoorman, J.J. (2009) Using Cover Crops to Improve Soil and Water Quality. Extension Fact Sheet, the Ohio State University, ANR-57. https://ohioline.osu.edu/factsheet/anr-57

[6] Williams, M.R. (2011) Cotton Insect Losses-2010. In Proceedings of the Beltwide Cotton Conferences, National Cotton Council of America, Memphis, 4-7 January 2011, 941-988.

[7] Williams, M.R. (2012) Cotton Insect Losses-2011. In Proceedings of the Beltwide Cotton Conferences, National Cotton Council of America, Memphis, 3-6 January 2012, 1013-1058.

[8] Williams, M.R. (2016) Cotton Insect Losses-2015. In Proceedings of the Beltwide Cotton Conferences, National Cotton Council of America, Memphis, 5-7 January 2016, 507-526.

[9] Blasingame, D. and Patel, M.V. (2005) Cotton Disease Loss Estimate Committee Report. In 2005 Proceedings of the Beltwide Cotton Conferences, National Cotton Council of America, Memphis, 4-7, January 2005, 259-262.

[10] Koenning, S.R., Overstreet, C. and Noling, J.W. (1999) Survey of Crop Losses in 
Response to Phytoparasitic Nematodes in the United States for 1994. Supplement to the Journal of Nematology, 31, 587-618.

[11] Starr, J.L., Koenning, S.R. and Kirkpatrick, T.L. (2007) The Future of Nematode Management in Cotton. Journal of Nematology, 39, 283-294.

[12] Koenning, S.R., Kirkpatrick, T.L. and Starr, J.L. (2004) Plant-Parasitic Nematodes Attacking Cotton in the United States: Old and Emerging Production Challenges. Plant Disease, 88, 101-113. https://doi.org/10.1094/PDIS.2004.88.2.100

[13] D'Addabbo, T. and Sasanlli, N. (1997) Suppression of Meloidigyne Incognita by Combinations of Olive Pomace or Wheat Straw with Urea. Nematol Mediate, 25, 159-164.

[14] Khalilian, A., Batchelder, D.G., Self, K. and Summers, J.D. (1984) Revision of Fuel Consumption Equations for Diesel Tractors. ASAE, New Orleans, 84-1522.

[15] Summers, J.D., Khalilian, A. and Batchelde, D.G. (1986) Draft Relationship of Primary Tillage in Oklahoma Soils. Transactions of the ASAE, 29, 37-39. https://doi.org/10.13031/2013.30097

[16] Hood, C.E., Khalilian, A., Palmer, J.H., Garrett, T.R. and Hayes, J.C. (1991) Double-Cropping Interseeding System for Wheat, Soybean and Cotton. Applied Engineering in Agriculture, 7, 530-536. https://doi.org/10.13031/2013.26263

[17] Khalilian, A., Hood, C.E., Palmer, J.H., Garner, T.H. and Bathke, G.R. (1991) Soil Compaction and Crop Response to Wheat/Soybean Interseeding. Transactions of the ASAE, 34, 2299-2303. https://doi.org/10.13031/2013.31871

[18] Khalilian, A., Jones, M.A., Bauer, P.J. and Marshall, M.W. (2017) Comparison of Five Tillage Systems in Coastal Plain Soils for Cotton Production. Open Journal of Soil Science, 7, 245-258. https://doi.org/10.4236/ojss.2017.710018

[19] Foote, W., Edmisten, K., Bacheler, J., Nuti, R., Wells, R., Jordan, D. and Fisher, L. (2014) Thrips and Cotton Response to Relay Intercropping with Wheat in North Carolina. The Journal of Cotton Science, 18, 94-107. http://journal.cotton.org 